\title{
İntranet-Tabanlı Bilişim Teknolojileri Servis Yönetimi Uygulamas1
}

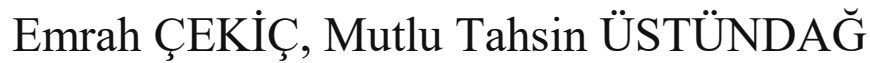 \\ Gazi Üniversitesi, Gazi Eğitim Fakültesi, Bilgisayar ve Öğretim Teknolojileri Eğitimi Bölümü \\ emrahcekic.gazi@gmail.com, mutlutahsin@gmail.com \\ (Geliş/Received: 29.06.2016; Kabul/Accepted: 30.02.2016) \\ DOI: $10.17671 / \mathrm{btd} .74045$
}

\begin{abstract}
Özet- Günümüz organizasyonları, rekabet ortamında başarılı ticaret yapabilme ve iş süreçlerindeki gereksinimlerini karşılayabilme amacıyla yoğun bir şekilde Bilişim Teknolojilerini (BT) kullanır hale gelmişlerdir. Artık bir bağımlılık olarak karşımıza çıkan BT kullanımı, servislerde kalite kavramının sorgulanmasına da öncülük etmektedir. Bir organizasyonda BT kalitesinden bahsetmek çalışanların ihtiyaçları ile iş süreçlerinin birlikte değerlendirilmesini gerektirmektedir. Organizasyonların, büyüklüğü ve türüne (kamu, özel vb.) bakılmaksızın uygun maliyetli, güvenilir, sürdürülebilir ve kaliteli servis alma ihtiyaçlarının olduğu söylenebilir. BT hizmet yönetimi, organizasyonların iş ihtiyaçlarına uygun BT hizmetlerinin sağlanması ve yönetilmesini ifade eden bir kavramdır. Hizmet yönetiminin oturtulmadığı organizasyonlarda BT hizmetlerin kalitesinden ve sürekliliğinden bahsetmek çok zordur. Kalite ve süreklilik için sistematik bir BT yönetim anlayışının yürütülmesi gerekmektedir. Bu noktada yapılacak örnek uygulamaların pratik iş süreçleri ve alanyazına katkı sağlayacağı düşünülmektedir. Bu çalışmada organizasyonların BT bölümlerine gelen iş taleplerinin hızlı uygulama geliştirme araçlarıyla geliştirilen intranet tabanlı bir uygulama üzerinden veritabanına kaydedilebilmesi, bu verilerin bilgiye dönüştürülebilmesi ve bilgilerin analiz edilerek yorumlanabilmesi konularına değinilmektedir.
\end{abstract}

Anahtar Kelimeler - Servis yönetimi, hızlı uygulama geliştirme, SharePoint, iş akış1

\section{Intranet-Based Information Technology Service Management Application}

\begin{abstract}
With the concern of achieving commercial goals and meeting the business needs in global competition environment, organisations have become increasingly dependent on IT (Information Technologies) today. This dependency leads investigating "quality" in IT services. In order to reach "quality" in IT services, organizations should consider the needs of personnel and business processes together. No matter how big and which type an organisation is, there is a need of economic, reliable, consistent and high-quality IT services. IT service management means providing and managing proper IT services towards business needs. In organisations lacking the sense of Service Management there is always uncertainty of service quality and consistency of IT. We can talk about quality and consistency if a systematic view of IT management is adopted. In this context, sample implementations of IT service management are expected to be valuable for both practice and related literature. In this study, it is mentioned that business demands in organisations are registered to a data base through intranet-based application to be developed without high programming skills and that data is turned into information and this information is analysed and interpreted.
\end{abstract}

Keywords - Service management, rapid application development, SharePoint, workflows

\section{GİRIŞ (INTRODUCTION)}

Günümüz işletmelerinin iş süreçlerini sorunsuz ve rekabet şartlarına uygun şekilde yürütmeleri Bilişim Teknolojileri (BT) bölümlerinin başarısı ile doğru orantılı olduğu görülmektedir. Servis yönetimi mantığından yoksun işletmelerde sunulan hizmetlerin kalitesi ve devamlılı̆̆ tartışmalıdır. Belirli bir sürece göre hareket edilmeden verilen hizmetlerde kalite ve süreklilik sağlamak mümkün değildir [1]. Bilgisayar teknolojisindeki gelişmeler, beraberinde BT'ni, iş dünyası için en önemli destek unsuru haline getirmekte ve getirmeye de devam etmektedir [2]. Günümüzde BT servislerinin yönetimi, organizasyonların stratejik hedeflerine ulaşmaları için bir gerekliliktir [3]. Günümüzde artık insanların günlük yaşamında veya iş hayatında ihtiyaç duydukları bilgilere hızlı ve kolay erişebilmeleri ve bu bilgilerden verimli sonuçlar üretebilmeleri çok önemlidir. İşte bu noktada BT'nin 
sunduğu imkanlar bu gibi ihtiyaçlara çözüm sunabilmektedir [4]. Müşteriler ve işletmeler arasındaki, işletmeler ve diğer işletmeler arasındaki, çalışanlar ve işletmeler arasındaki, işletmeler ve devlet arasındaki dijital etkileşim her geçen gün artmakta ve artarak devam etmektedir. Bu dijital etkileşim işletmelerin BT bütçelerini ve BT yatırımlarını artırmaktadır. Günümüzde, BT bölümleri basit bir yardım masası görevini üstlenmekten daha ileriye gitmekte, görev kapsam ve sorumlulukları değişmektedir. $\mathrm{Bu}$ değişim $\mathrm{BT}$ bölümlerine, organizasyonların teknoloji süreçlerine geniş bir yelpazede destek vermek ve süreçlerde liderlik üstlenmek gibi sorumluluklar yüklemektedir [5]. BT'nin iş süreçlerinde kullanımı yaygınlaştıkça, sunulan BT hizmetlerinin kalitesi ve başarısı, doğrudan işlerin başarısına ve kurumun başarısına etki etmektedir. BT bölümlerinin sorumluluk sahası genişlemektedir. Sürekli genişleyen sorumluluk sahası, BT bölümlerinden talep edilen iş isteklerini arttırmaktadır. $\mathrm{Bu}$ artış beraberinde bölüm içi zaman yönetimi, envanter yönetimi, stratejik karar alma süreçleri, organizasyon içi sorunlara hızlı ve etkili yanıt verme becerisi, organizasyon çalışanlarına verilen hizmet kalitesi gibi kritik başlıkların yönetimini olanaksız hale getirmekte ve bölüm içi verimliliği düşürmektedir.

Tüm bu problemler göz önüne alındığında, servis yönetiminin istikrarlı, şeffaf ve ölçülebilir olmasının büyük önem taşıdığı söylenebilir. Bu kadar büyük verilerin depolanması, işlenmesi ve bu verilenlerden anlamlı sonuçlar elde edilmesi bilinen yöntemlerin ötesinde bir teknik ve donanım çözümü gerektirmektedir [6]. Bu tespitten yola çıkarak, organizasyon çalışanlarının BT bölümlerinden talep ettikleri iş isteklerini yönetilebilmesi, bu isteklerin bir veritabanında toplanabilmesini gerektirir. Toplanan bu verilerin bilgiye dönüştürülmesi ve bilginin analiz edilerek yorumlanabilmesi içinse karar destek sistemlerine ihtiyaç duyulmaktadır. $\mathrm{Bu}$ sistemler bir kararın verilmesi için gerekli olan verileri analiz ederek karar verme etkinliğini artıran ve karar alıcılara yol gösterici olan bilgisayar tabanlı bilişim sistemleridir. [7, 8]. Karar destek sistemleri ile elde edilen sonuçlar, kullanıcılarına istatistiksel bilgiler sunmalıdır. Sunulan bu bilgilerin anlamlandırılması ve bu bilgilerden sonuçlar çıkarılabilmesi için karar destek sistemlerinin aşağıdaki niteliklere uygun olması beklenir:

- Elde edilen tüm verilerin sinıflandırılarak, analiz edilebilmesi ve ortaya çıkan sonuçların izlenebilmesi.

- Elde edilen sonuçların zaman noktasında yıl, ay, gün, gibi kırılımlara ayrılabilmesi ve bu sonuçların karşılaştırılabilmesi.

- Sonuçların analizinden yola çıkılarak geleceğe yönelik tahminlemeler yapılabilmesi ve öngörü oluşturulabilmesi.

- Deneyimlerin veriler ile desteklenmesi ve geleceğe yönelik farklı senaryolar arasından alternatifler üretilebilmesi [9].

$\mathrm{Bu}$ çalışmada, organizasyon çalışanlarının BT bölümlerinden talep ettikleri iş isteklerinin istikrarlı, şeffaf ve ölçülebilir bir şekilde yönetilebilmesi gerekliliğinden yola çıkılarak, organizasyonların ihtiyaçlarını karşılayabilecek, asgari programlama bilgisiyle hızlı uygulama geliştirme araçlarından yararlanarak intranet tabanlı bir uygulama geliştirilmiştir. İntranet tabanlı kurumsal içerik yönetim portalları, çalışanların işlerini kolaylaştıran, standart ofis uygulamalarının ötesinde hizmet sunan, bilgiyi etkili yöneten ve bilgilerden anlamlı sonuçlar üretebilen yazılımlardır [4].

$\mathrm{Bu}$ çalışmada, öncelikle intranet tabanı üzerinde geliştirilmiş olan uygulamanın kurulum aşamalarına, daha sonra uygulamanın BT bölümlerine gelen iş isteklerini nasıl yönetebileceğine ve son olarak, bu iş isteklerinin nasıl analiz edileceğine değinilmektedir. Bu uygulama kurumsal bir içerik yönetim portalı olan SharePoint üzerinde geliştirilmiştir. SharePoint, dosya paylaşımı ve kurumsal işbirliği için Microsoft tarafından geliştirilen bir yazılımdır [10].

$\mathrm{Bu}$ makalede, geliştirilen uygulamada SharePoint yazılımının tercih edilmesinin nedenleri; şu şekilde ifade edilebilir:

- SharePoint'in çok çeşitli firmalar tarafından yaygın kullanılan başarılı bir paylaşım, yönetim ve takip programı olmasi,

- SharePoint ile güncel veriye istenilen her yerden erişilebilmesi,

- SharePoint'in çift taraflı veri okuma ve yazma özelliğinin sayesinde başka veri depolarına erişilebilmesine imkan sağlaması, bu veri depolarını görüntüleyebilmesi ve değiştirebilmesi,

- SharePoint'in birden fazla kullanıcıya tekil oturum açma teknolojisi ile (single sign-on) aynı anda herhangi bir çalışma alanına veya kaynağa erişme kabiliyeti sağlayan benzersiz bir altyapı sunmasıdır [10]. Bununla birlikte bu mekanizma SharePoint üzerinde geliştirilecek olan uygulamaya karşı gösterilecek teknoloji direncinin kırılması ve işlevselliği açısından göz ardı edilmemesi gereken bir teknoloji olarak karşımıza çıkmaktadır. Tekil oturum açma (single sign-on) tek bir kullanıcı adı ve şifre ile dağıtık bir yapıdaki birden çok servise güvenli erişimi sağlayan kimlik doğrulama mekanizmasıdır.

[11].

- Son olarak SharePoint, işlerin takibini arttırmakta, farkındalık yaratmakta ve kolaylaştırmakta aynı zamanda iş yönetimi kalitesini en yüksek seviye çıkartmaktadır. Bu çalıșma kapsamında geliştirilen uygulama için, bütün bu özellikleri bir arada barındırdığından dolayı tercih edilen intranet tabanlı SharePoint ile birlikte, etki alanı servis hizmetleri, Microsoft ağlarında kullanılan dizin hizmetinden, alan adı servisleri, dinamik istemci yapılandırma protokolünden ve tekil oturum 
açma teknolojisinden yararlanılmıştır. Aynı zamanda ekip üretkenliğini ve verimliliğini arttıran asgari yazılım bilgisiyle geliştirilmesi mümkün olan iş akış şemaları kullanılmıştır. (İş akışı, bir başlangıcı, bir sonu ve başlangıçtan sona kadar sıralı bir akışı olan eylemlerin akış çizelgesi olarak düşünülebilir.) Bu uygulamanın temel amacı, organizasyonlar içinde görev alan her BT çalışanı için SharePoint üzerinde kodsuz uygulama geliştirebilmesinin mümkün olduğunu göstererek BT bölümlerine gelen iş isteklerinin bir veritabanında toplanabilmesini, bu verilerin bilgiye dönüştürülerek analiz edilebilmesini ve yorumlanabilmesini sağlamaktır.

Uygulamanın gerçekleştirilme aşamalarında üzerinde durulan bir diğer önemli konu ise teknoloji direncidir. BT kullanılmadıkça organizasyonlara fayda sağlamazlar, ne yazık ki BT'ne karşı gösterilen direnç organizasyon çalışanlarında ve yöneticilerinde oldukça yaygın bir sorundur [12]. Çalışanların değişime dirençleri, organizasyonda yapılmaya çalışılan değişimlere engel olma, güvensizlik ve şüphe duyma anlamına gelmektedir. Çalışanlar değişimlere çeşitli kaygıları nedeniyle direnç gösterebilmektedirler [13]. $\mathrm{Bu}$ direnç çeşitli biçimlerle kendini göstermektedir. Örneğin geliştirilecek olan uygulama üzerinde kullanıcıların bir bölümü mevcut sistem ile ilgili herhangi bir şikâyet dile getirmezken, bu sistemi kullanmak yerine, farklı arayışlarına girerek eposta, telefon, yüz yüze sözlü aktarım gibi alternatif yollardan sistemin işlerliğini olumsuz yönde etkileyebilirler. Bu çalışmada tüm bu yaklaşımlar göz önünde bulundurularak teknoloji direncini fark etme ve çözme yönünde tedbirler geliştirilmiştir. Uygulamanın tüm geliştirme aşamaları son kullanıcılardan gelen geri bildirimler ile beslenerek organizasyon çalışanlarına, bu uygulamadan toplanan bilgilerin yorumlanarak çalışanların aldıkları BT servis kalitesinin arttırılmasına yönelik geliştirmeler yapılacağı izah edilmiştir. Canlı sistemde kullanıcılara verilen hizmetin kalitesi ve ortaya çıkan problemlerin kısa sürede çözülmesi teknoloji direncinin kırılması noktasında belirleyici olmuştur. Literatüre bakıldığında BT bölümlerinin örgütler için anahtar bir rol üstlendiğini söylemek mümkündür. $\mathrm{Bu}$ bağlamda ortaya konan çalışmanın, İntranet tabanlı kurumsal içerik yönetim portalı olan SharePoint üzerinde gerçekleştirilen ilk çalışmalar arasında olma özelliği ile literatüre önemli bir katkı sunacağı düşünülmektedir.

\section{UYGULAMANIN AMAÇ VE KAPSAMI (OBJECTIVES AND SCOPE OF APPLICATION)}

Bilişim teknolojilerinin hızla gelişmesi, iş süreçlerini her geçen gün daha çok bilişim teknolojilerine bağımlı duruma getirmekte ve bu durum, kurumların BT bölümlerinin iş yükünü artırmaktadır. Artan iş yükü beraberinde karmaşık ve yönetilmesi güç bir teknolojik çıkmaz yaratmaktadır. $\mathrm{Bu}$ noktada makalenin amac1, kapsamı ve etki alanı aşağıdaki şekilde sıralanmaktadır;
- Amaç: BT bölüm çalışanlarının gün içinde karşılaştıkları bilişim teknolojilerine ait iş isteklerini yönetebilecekleri bir yapının intranet tabanı üzerinde geliştirilebilmesidir. Bununla birlikte,

Telefon ya da e-posta gibi analizi zor olan iletişim kanallarından gelen iş isteklerini, asgari yazılım bilgisiyle geliştirilen intranet tabanlı bir uygulama üzerine yönlendirmek ve bu sayede gelen iş isteklerini projede belirlenen kırılımlar bazında kategorize etmektir.

- Kapsam ve etki alant: Küçük, orta veya büyük ölçekli özel ya da kamu kurumlarının BT bölümleridir. $\mathrm{Bu}$ uygulamada tasarlanan teknolojik altyapı tüm organizasyonların BT altyapısına uyum gösterecek şekilde yapılandırılmıştır.

- Çalışmada kullanılan yazılım teknolojileri: $\mathrm{Bu}$ projede Microsoft firmasina ait SharePoint yazılımının ücretli sürümü olan SharePoint 2010 Server kullanılmıştır. Uygulamanın geliştirilmesi aşamalarında, Microsoft ürün ailesine ait olan SharePoint Designer 2010 ve InfoPath Designer 2010 sürümleri kullanılmıştır.

\section{SHAREPOINT MIMARISI (SHAREPOINT ARCHITECTURE)}

SharePoint mimarisi fiziksel öğeleri barındırmayan SharePoint yapısını anlatan mimaridir. İş süreçlerini tanımlayan ve projedeki öğelerin hangi amaçla kullanıldığını gösteren yapıdır.

\subsection{SharePoint Mimari Bileşenleri (SharePoint Architecture Components)}

- Sunucu Çiftlikleri (Server Farms): Sunucu çiftlikleri SharePoint yapısında en yukarıda yer alan elementtir. Sunucu çiftlikleri basit bir tanımla, bir veya birden fazla SharePoint sunucusu kurularak oluşturulan sunucu topluluğudur [14].

- Servis Uygulamalarl (Service Applications): Servis uygulamaları, web uygulamaları veya SharePoint yerleşkeleri tarafindan paylaşılabilecek şekilde kaynaklar sunan yapılardır. En bilinen servis uygulaması Excel servis uygulamasidir. $\mathrm{Bu}$ servis sayesinde SharePoint üzerinde Excel formları ve özellikleri kullanılabilmektedir. Buna benzer diğer servis uygulamaları ise Visio, Word, Access gibi servis uygulamalarıdır [14].

- Uygulama Havuzlarl (Applications Pools): Uygulama havuzları bir veya birden fazla tek düzen kaynak bulucuya (URL) hizmet eden ve sunucu üzerinde kendi işlem proseslerine sahip olan yapılardır. Her uygulama havuzunun sahip olduğu bir işlem prosesi ve bu prosese atanmış güvenlik hesabı mevcuttur [14].

- Web Uygulamalarl (Web Applications): Web uygulaması SharePoint de oluşturulan ve kullanılan internet bilgi hizmetleri (IIS) Web 
Sitesi'dir. Bir web uygulaması içerisinde beş farklı bölge oluşturulabilir. $\mathrm{Bu}$ bir web uygulamasında beş farklı web sitesi kullanılabileceği anlamına gelir [14].

- Bölgeler (Zones): Bölgeler aynı web uygulamasına erişmek için kullanılan farklı URL yollarını ifade eden mantıksal yapılardır [14].

- İçerik Veritabanı (Content Database): Varsay1lan olarak web uygulamasının tüm içeriği tek bir içerik veritabanında tutulur. İçerik birden fazla veritabanında tutulabilecek şekilde tasarlanabilir [14].

- Site Koleksiyonlar (Site Collections): Site koleksiyonları SharePoint mantıksal yapısının en önemli bileşenlerinden birisidir. Site koleksiyonları aynı üst seviye siteyi paylaşan siteler topluluğudur. Her site koleksiyonu sadece bir üst seviye siteye sahiptir. Site koleksiyonlarının birden fazla alt siteleri olabilir. Site koleksiyonları birbirlerinden bağımsızdırlar, her birinin kendine özgü güvenlik modeli, depolama alanı ve yapılandırma ayarları vardır [14].

- Siteler (Sites): Siteler mantıksal bileşenleri barındıran yapılarıdır. Listeler, kütüphaneler, yapılandırma ayarları gibi bileşenler siteler içerisinde tutulurlar. Siteler bir veya birden fazla web sayfasına sahip olabilirler [14].

- Listeler ve Kütüphaneler (Lists and Libraries). Kontaklar, atamalar, dokümanlar gibi benzer bileşen topluluklarını barındıran mantıksal bir kümeleme yapısıdır. Liste ve kütüphane kavramlarını, farklı veri tiplerini içeren ve kolonları barındıran veritabanı tablolarına benzetilebilir [14].

- Öğgeler (Items): Öğeler en küçük mantıksal elemanlardır. Kişi, doküman, liste ve kütüphane kavramlarındaki tek bir satır veri, öğelere örnek olarak verilebilir [14].

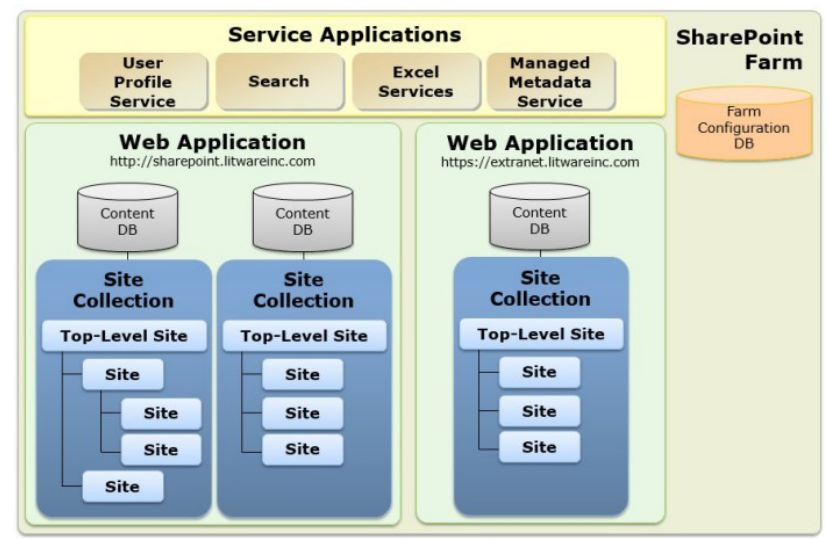

Şekil 1.SharePoint Mantıksal Mimarisi (SharePoint Logical Architecture)

\section{GERÇEKLEŞTİRIMLER (IMPLEMENTATIONS)}

Uygulama intranet tabanlı bir web uygulaması olarak tasarlanmıştır. Uygulama, etki alanı üyesi olan sanal bir sunucu üzerinde yapılandırılmakta ve uygulamanın geliştirme süreçleri aşağıdaki konu başlıklarıyla açıklanmaktadır:

\subsection{Uygulamanın Sunucu Üzerinde Yapılandırlması (Configuring the Application on Server)}

Fiziksel bir sunucu üzerine kurulu olan "VMware ESXi 5.5" üzerinde "BT" adiyla "itc.global.mahle" etki alanı üyesi bir "Windows Server 2008" işletim sistemi sanal makina üzerine kurulmuş ve bu işletim sistemi üzerinde "SharePoint 2010 Server" yapılandırılmıştır. VMware bir sanallaştırma teknolojisidir, bu teknoloji ile birlikte fiziksel bir donanım üzerinde sanal sunucular oluşturulabilmektedir [15]. Kurum içerisinde kullanılmakta olan dizin hizmeti (Active directory) servisi sayesinde kullanıcılar SharePoint sunucusuna herhangi bir kullanıcı adı ve şifre girişi yapmaksızın direk erişim sağlamaktadırlar. $\mathrm{Bu}$ kolaylık teknoloji direncinin kırılması noktasında büyük önem taşımaktadır. Dizin hizmeti bir ağ sevisidir. Kaynaklarla ilgili tuttuğu verileri kullanıcıya veya uygulamaya sunar. Dizin hizmeti ortamdaki ağ altyapısına büyük ölçüde işlevsellik kazandırmaktadır. Dizin hizmeti ayrıca, sisteme önceden kayıt olan kullanıcıların, oturum açmak suretiyle, ağdaki kaynaklara güvenli erişimleri noktasında sistem yöneticilerinin işini kolaylaştırır [16].

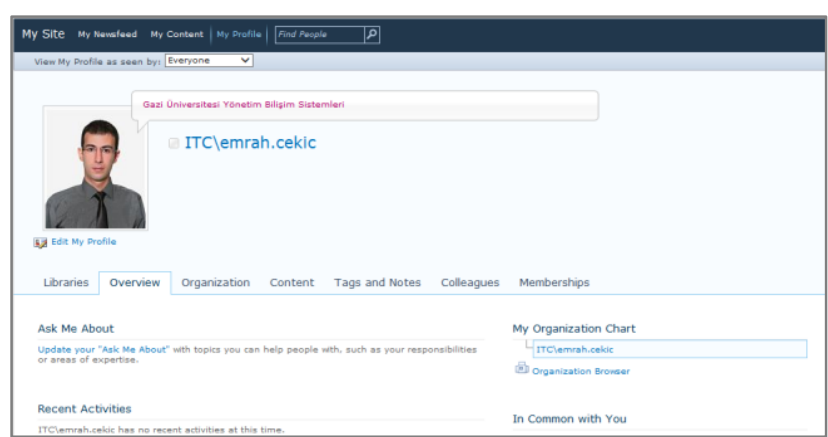

Şekil 2. Uygulamaya Direk Erişim (Direct Access to Applications)

$\mathrm{Bu}$ uygulama sistematik bir yaklaşımla ihtiyaçlar doğrultusunda gerçekleştirilen bir uygulama olmasının yanında, kurumun bilgi sistemlerine bütünleşik inşa edilmiş bir uygulama olmasıyla da önem taşımaktadır. Uygulamanın kurum içeresindeki diğer sistemler ile bütünleşik bir şekilde yapılandırılması, yetki dağıtımı, güvenlik, uygulamaya erişim gibi birçok noktada fayda sağlamaktadır. 


\subsection{Uygulamanın SharePoint Üzerinde Yapılandırması (Configuring the Application on SharePoint)}

Uygulamanın geliştirilmesi aşamalarında oluşturulan alanlar, SharePoint yazılımının liste ve kolon özellikleri kullanılarak oluşturulmuştur. Liste SharePoint'de kolonlara satırlar üzerinden ulaşabilmek için geliştirilmiş bir araçtır. Listeleri veritabanları içerisindeki tablolar olarak değerlendirmek mümkündür. Kullanıcı adları, telefon numaraları, e-posta bilgileri ve daha birçok verinin saklanabileceği bu alanlar hiç bir "SQL" sorgusuna gerek kalmadan sorgulama yapma imkanı tanımaktadır. Kolonlara karşılık olarak ise tablo kolonlarını göstermek yanlış olmayacaktır. SharePoint üzerindeki kolon yapısı daha gelişmiş ve kolay bir kullanıma sahiptir. Kolon türü olarak yazı, sayı ve hatta link, resim gibi seçimler yapmak mümkündür [17]. Bu mantık üzerinden geliştirilen alanlar üç ana başlık altında tasarlanmaktadır. Bunlar;

\subsubsection{Kullanıcı Olayı (User Incident)}

Kullanıcılar yaşadıkları bilişim teknolojilerine ait problemlerini ve isteklerini bu bölümde tanımlamaktadırlar. Kullanıcıların gösterdiği teknoloji direncinin kırılması noktasında bu arayüz basit, sade ve açılır menüler ile kullanımı kolay bir şekilde tasarlanmıştır. $\mathrm{Bu}$ yöntemle hedeflenen teknoloji direncinin asgari düzeyde seyretmesini sağlamaktır.

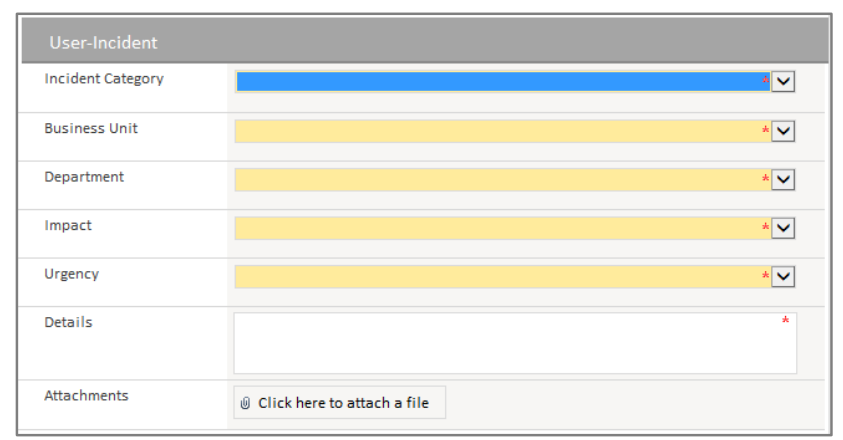

Şekil 3. Kullanıcı Olayı (User Incident)

$\mathrm{Bu}$ bölümde yer alan tanımlamalara aşağıda değinilmektedir:

- $\quad$ Olay Kategorisi (Incident Category): İş isteğinin hangi kategoriye girdiğini tanımlamaktadır.

- İş Tesisi (Business Unit): İş isteğinin hangi tesisten yapıldığını tanımlamaktadır.

- Departman (Department): İş isteğinin hangi departmandan yapıldığını tanımlamaktadır.

- $\quad$ Etki (Impact): İş isteğinin etkisinin ne olduğunu tanımlamaktadır.

- Aciliyet (Urgency): İş isteğinin aciliyetini tanımlamaktadır.

- Detaylar (Details): İş isteğine ait detayları tanımlamaktadır.

- Eklentiler (Attachments): İş isteğine ait resim, video ve benzeri eklentilerin eklendiği alandır.

\subsubsection{Olay Açıklamaları (Incident Description)}

$\mathrm{Bu}$ bölümünde yer alan bilgilerin, kurumların $\mathrm{BT}$ çalışanları tarafından doldurulması planlanlanmıştır. Bu sebeple bu bölüm, kullanıcılar tarafından düzenlemeye kapatılacak şekilde tasarlanmıştır. Kullanıcıların iş isteklerinin tamamlanmasının ardından BT çalışanı ilgili iş isteğine ait bilgileri bu alana girmekte ve kullanıcı iş isteğine ait gelişmeleri bu bölüm üzerinden takip etmektedir. Bu yapı sayesinde kullanıcı iş isteğine ait tüm gelişmeleri şeffaf bir yapı üzerinden takip edebilmektedir. $\mathrm{Bu}$ yöntemle hedeflenen kullanıcının uygulamaya duyduğu güvenin artırılması ve uygulamanın kullanımının kurum içinde kısa sürede yaygınlaştırılmasının sağlanmasıdır.

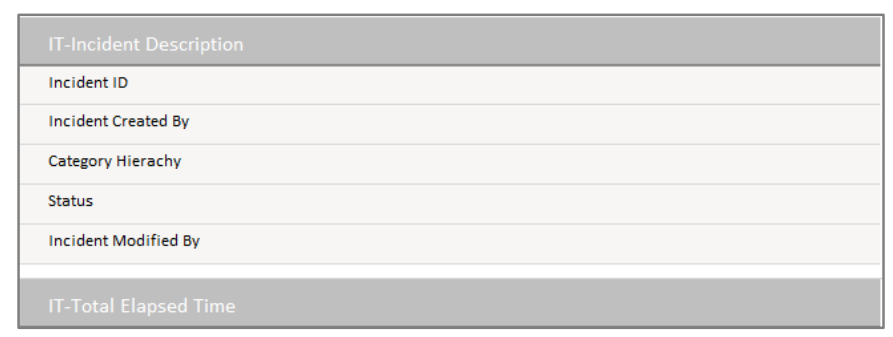

Şekil 4. Olay Açıklamaları (Incident Description)

$\mathrm{Bu}$ bölümde yer alan tanımlamalara aşağıda değinilmektedir:

- $\quad$ Olay Kimlik Numarası (Incident ID): Bu numara her bir iş isteğinin sisteme girilmesinin ardından sistem tarafından benzersiz bir şekilde oluşturulmakta ve ilgili alana otomatik olarak yerleştirilmektedir.

- Olayı Yaratan (Incident Created By): İş isteğini oluşturan kullanıcıya ait bilgiler, dizin hizmeti sayesinde bu alana otomatik olarak sistem tarafindan yerleştirilmekte, bu sayede iş isteğinin hangi kullanıcı tarafından oluşturulduğu takip edilebilmektedir.

- Kategori Hiyerarşisi (Category Hierachy): Kullanıcı tarafından oluşturulan iş isteğinin hangi problem kategorisinde yer aldığ tespit edilmekte ve BT çalışanı tarafından açılan menüden seçilmektedir.

- Durum (Status): Kullanıcı, iş isteğinin hangi aşamada olduğunu bu bölüm üzerinden takip etmektedir.

- Olayı Düzenleyen (Incident Modified By): Kullanıcı, iş isteğinin hangi BT çalışanı tarafından düzenlediği bilgisini bu bölüm üzeriden takip edebilmektedir.

\subsubsection{Toplam Geçen Süre (Total Elapsed Time)}

İş isteğinin oluşturulduğu, kapatıldığı ve iş isteği için BT bölümü tarafindan harcanan sürenin saat cinsinden hesaplandığı alandır. Bu bölüm, kullanıcılar tarafından düzenlemeye kapatılmış şekilde tasarlanmıştır. 


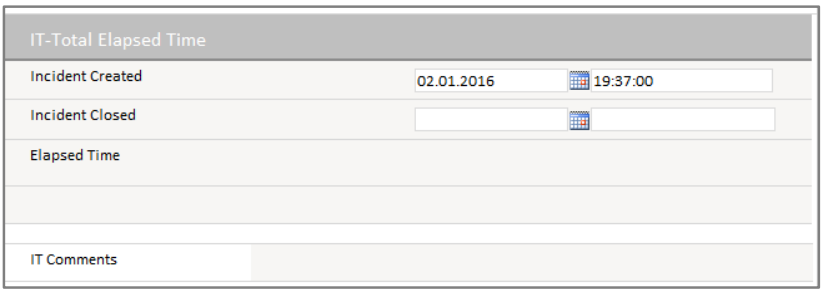

Şekil 5. Toplam Geçen Süre

(Total Elapsed Time)

$\mathrm{Bu}$ bölümde yer alan tanımlamalara aşağıda değinilmektedir:

- Olayın Oluşturulması (Incident Created): İş isteğinin oluşturulduğu tarih ve saate ait zaman damgası bu bölümde yer almaktadır.

- Olayın Kapatııışı (Incident Closed): İş isteğinin kapatıldığ 1 tarih ve saate ait zaman damgası bu bölümde yer almaktadır.

- Geçen Süre (Elapsed Time): İş isteğinin sonuçlandırılması için BT bölümü tarafindan harcanan sürenin formülle hesaplandığı alandır.

- BT Yorumları (IT Comments): İş isteğinin çözümlenmesi aşamalarında BT bölümü tarafindan kullanıcının bilgilendirilmesi adına yapılan yorumlar bu bölümde yer almaktadır.

Uygulama üzerinde yapılandırılan liste ve kolonların şematik görüntüsü Şekil 6'da gösterildiği gibidir:

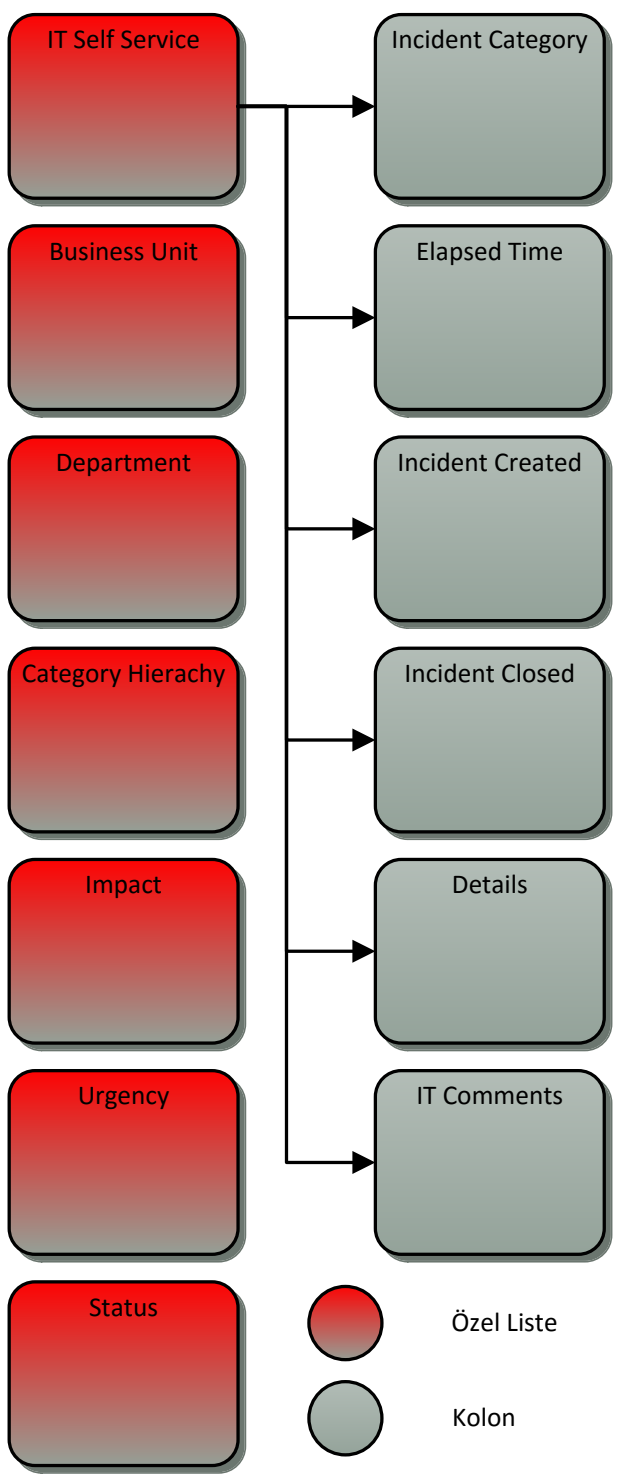

Şekil 6. Liste ve Kolonların Görünümü (View of The List and Column)

\subsection{Uygulamanın InfoPath Üzerinde Yapllandırması (Configuring the Application on InfoPath)}

Sharepoint üzerinde oluşturulan tüm alanların form üzerine yerleştirilmesi ve bu alanların görsel tasarımı "InfoPath" uygulamasında yapılandırılmıştır. Bu uygulama sayesinde kod bilgisi gerektirmeyen basit kurallar oluşturulmakta, bu sayede form kullanımına esneklik kazandırılmaktadır. Şekil 7'nin sağ bölümde yer alan alanlar, SharePoint üzerinde daha önce oluşturulmuş olan alanlardır. $\mathrm{Bu}$ alanlar form üzerine sürüklenerek bırakılmaktadır. $\mathrm{Bu}$ sayede form tasarımı kod bilgisi gerektirmeden sağlanmaktadır. 


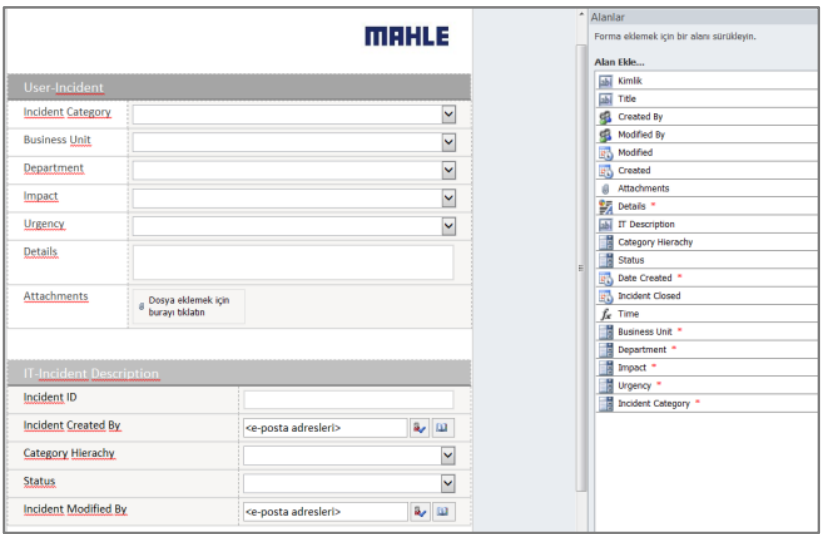

Şekil 7. Liste Öğelerinin Form Üzerine Yerleştirilmesi (Placing on The Form of List Items)

"InfoPath" üzerinde kural ve koşul yaratmak kod bilgisi gerektirmemektedir. Örnek olarak Şekil 8'de kullanıcılardan, İş ünitesi (Business Unit) alanına zorunlu veri girişi yapılması istenmektedir.

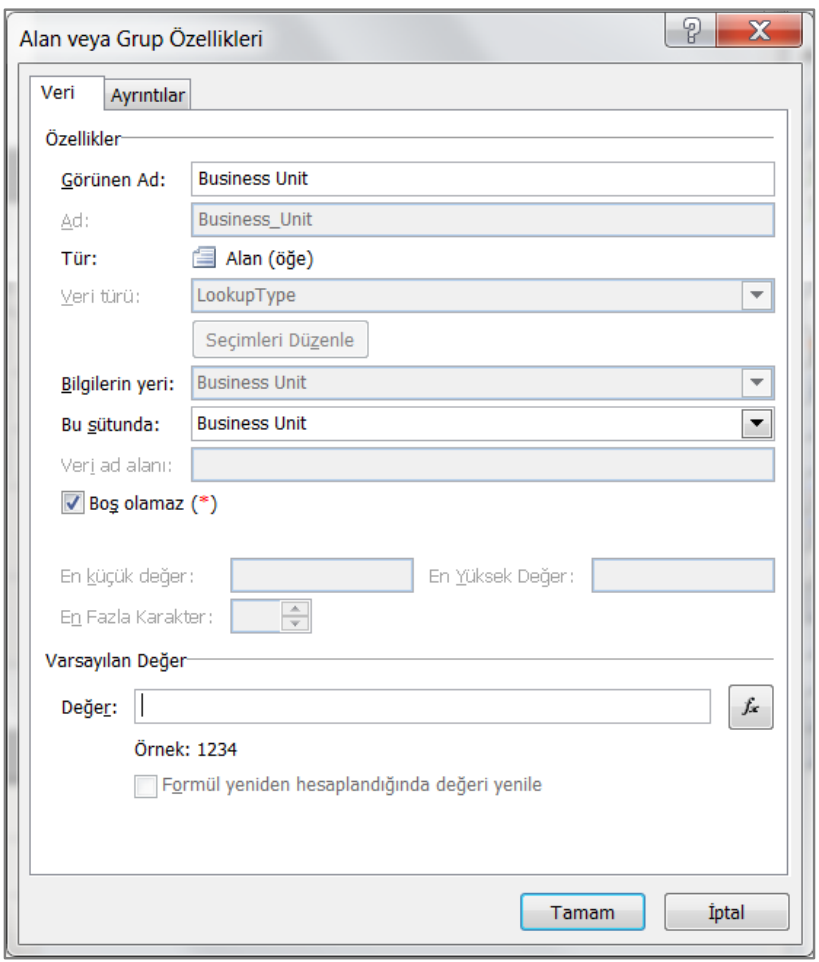

Şekil 8. InfoPath Üzerinde Kural Oluşturulması (Creating Rules on InfoPath)

Şekil 9'de verilen örnekte ise kullanıcı tarafindan durum (Status) alanına veri girişi yapılmaması istenmektedir. $\mathrm{Bu}$ durum göz önüne alınarak "InfoPath" üzerinde koşul oluşturulmaktadır.

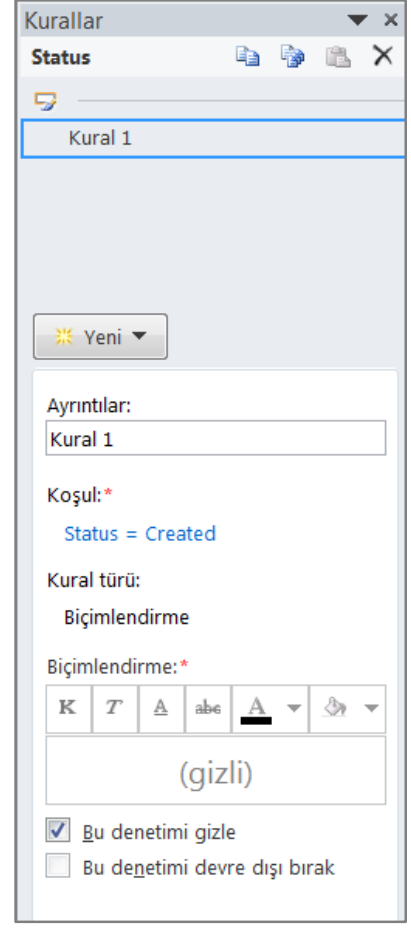

Şekil 9. InfoPath Üzerinde Koşul Oluşturulması (Creating Condition on InfoPath)

Formun tüm alanlarının tasarlanmasının ardından son görünümü Şekil 10'da gösterilmektedir. Kırımızı simgeli alanlar kullanıcıların veri girişi yapmak zorunda olduğu alanlardır.

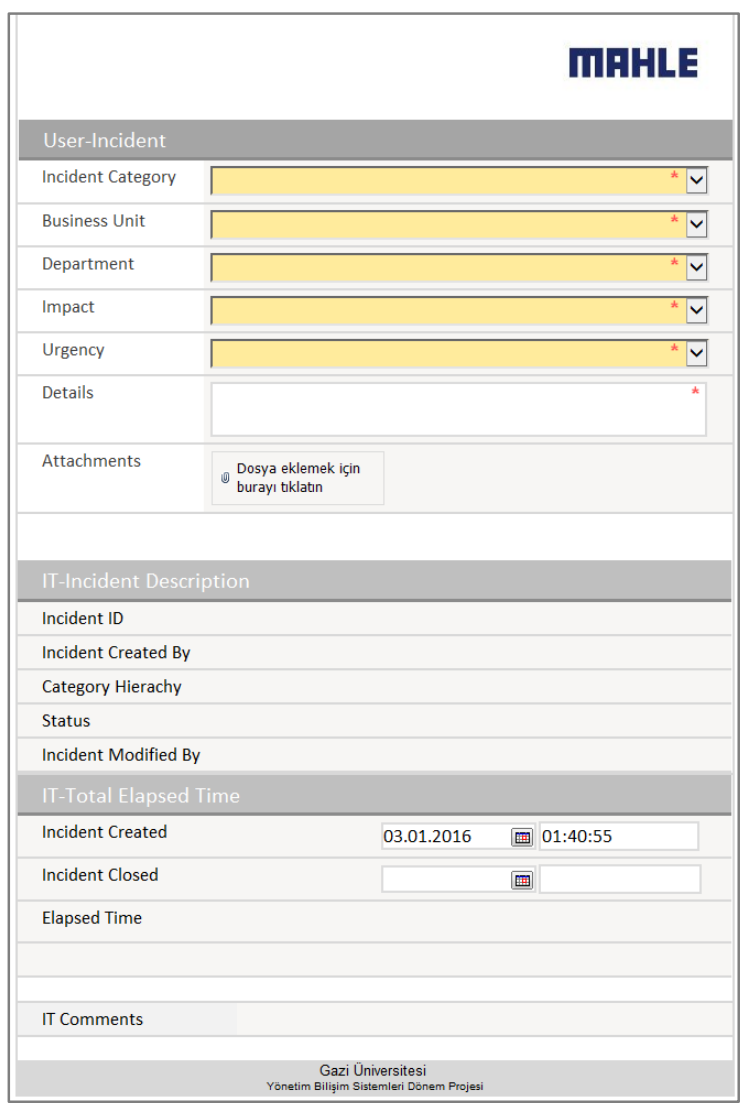

Şekil 10. Form Görünümü (Form View) 
7.1. Uygulamanin SharePoint Designer Üzerinde Yapllandırılmast (Configuring Applications on the SharePoint Designer)

SharePoint üzerinde oluşturulan liste ve kolonların, "InfoPath" ile form üzerinde tasarlanması, kural ve koşullar ile form üzerinde belirli kısıtlamaların uygulanmasının ardından son aşamada yer alan SharePoint Designer ile iş akışlarının oluşturulması kısımlarına bu bölümde değinilmektedir.

\subsubsection{Gruplarının Oluşturulması (Creating Group)}

İş akışları oluşturulmadan önce SharePoint üzerinde bu iş akışlarının hangi BT bölüm çalışanına veya çalışanlarına atanacağını belirlemek için gruplar oluşturulmaktadır. Bu gruplar aşağıdaki gibidir:

- Yetki Erişim (Access Authorization)

- Lokal Donanım (Hardware Local)

- Altyapi Servisi (Infrastructure Service)

- Organizasyonel Bilgilendirme (Organisation Information)

- İş Yazılımları (Software Business)

BT çalışanları sorumluluk sahalarına göre ilgili gruplara eklenmekte ve bu grup üyelerine SharePoint üzerinde tam yetkilendirme yapılmaktadır. Duruma göre bu yetkilendirmelerde kısıtlamalara gidilmesi mümkündür.

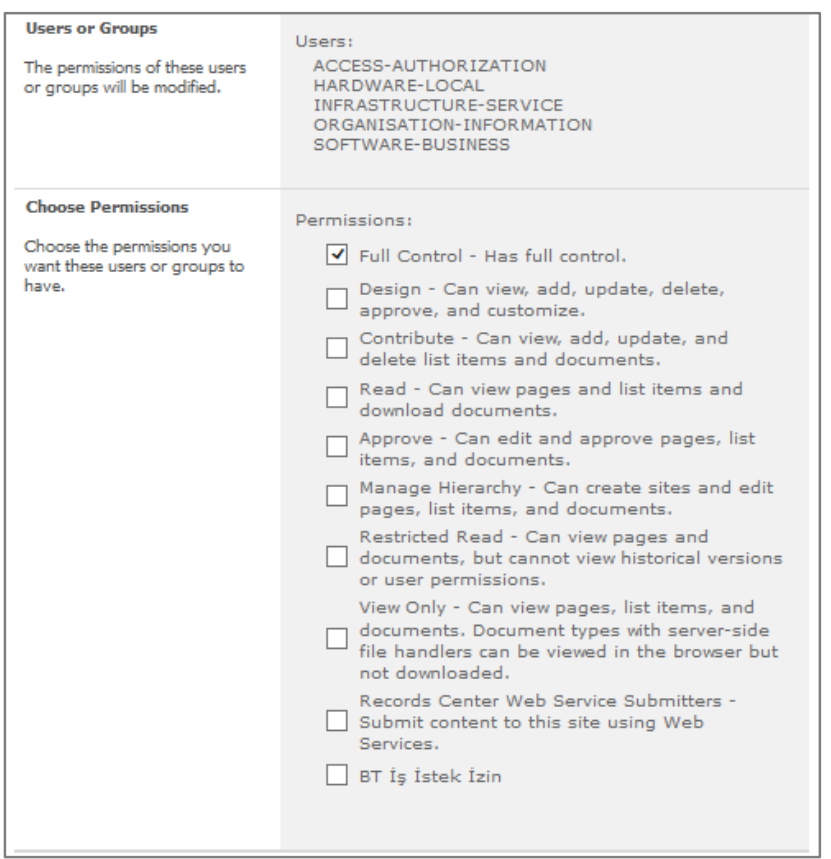

Şekil 11. Yetki Grupları

(Authorization Group)

\subsection{2. İş Akış Diyagramlarının Oluşturulması (Creating Workflow Diagrams)}

İş akışı, iş sürecine uyan eylemler serisini düzenleme ve çalıştırmanın doğal bir yolu olarak tanımlanmaktadır [17]. İş akışı kişilerin veya iş akışı katılımcılarının gerçekleştirdiği eylemler ve iş akışının gerçekleştirdiği eylemleri içermektedir. İş akışları, iş süreçlerinin gerektirdiği biçimde, karmaşık veya basit yapılarda olabilir. Kullanıcının başlattığı bir iş akışı veya bir liste öğesinin oluşturulması ya da değiştirilmesi gibi bir olay temelinde otomatik olarak başlatılan bir iş akışı oluşturur. $\mathrm{Bu}$ uygulamada iş akışının tetiklenebilmesi için kullanıcı bir iş isteği oluşturduğunda, ortaya çıkan problemin hangi olay kategorisine (Incident Category) girdiğini form üzerinden seçmek zorundadır. İş isteğinin kullanıcı tarafından kayıt altına alınmasının ardından uygulama, kullanıcının seçmiş olduğu kategoriye göre otomatik bir iş akışı başlatacak ve iş isteğini ilgili BT çalışanına atayacaktır.

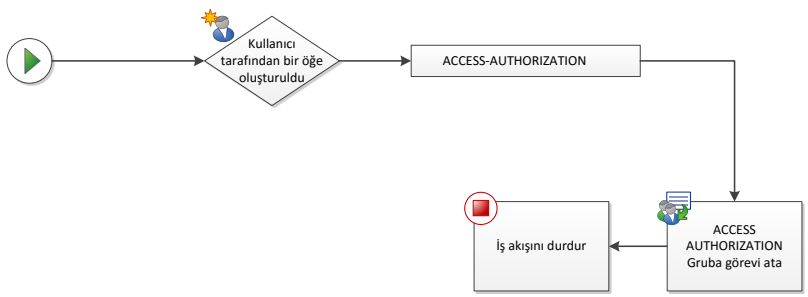

Şekil 12. Yetki Erişim İş Akış Şeması (Access Authorization Workflow Scheme)

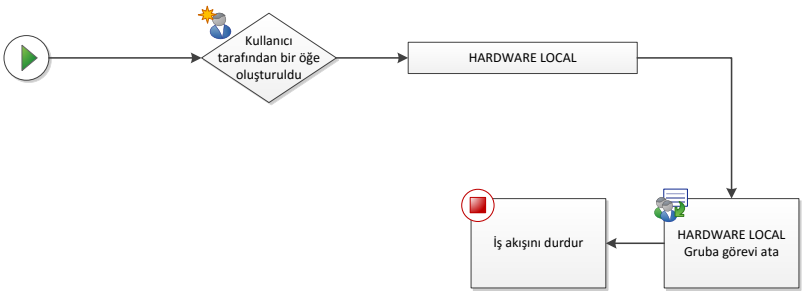

Şekil 13. Lokal Donanım İş Akış Şeması (Local Hardware Workflow Scheme)

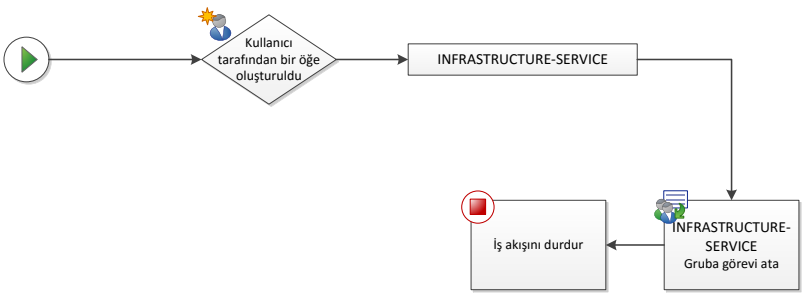

Şekil 14. Altyapı Servisi İş Akış Şeması (Infrastucture Service Workflow Scheme)

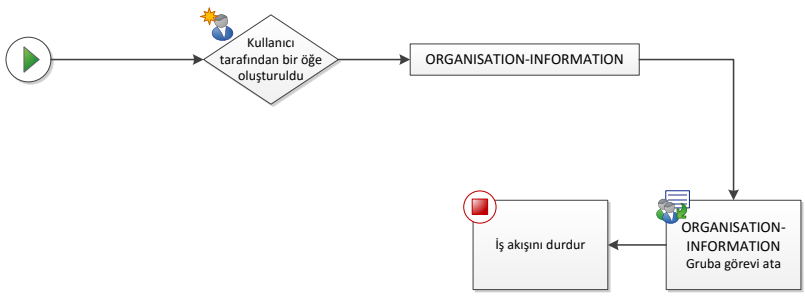

Şekil 15. Organizasyonel Bilgilendirme İş Akış Şeması (Organisation Information Workflow Scheme) 


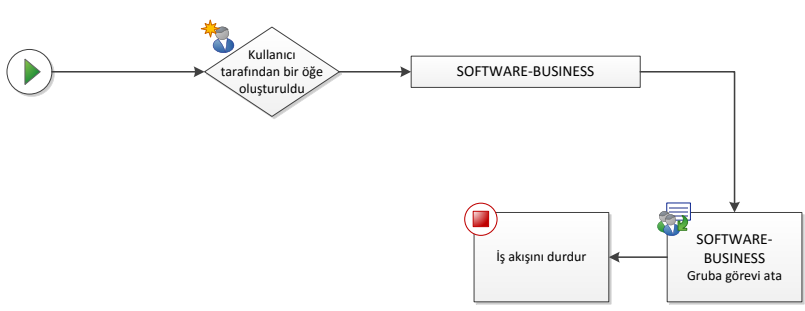

Şekil 16. İş Yazılımları İş Akış Şeması (Software Business Workflow Scheme)

\subsection{3. İş Aklşlarının SharePoint Designer Üzerinde} Tasarımı (On Design of Workflow in SharePoint Designer)

Tasarlanan iş akış diyagramlarının "SharePoint Designer" üzerinde yapılandırılmasının sayesinde kullanıcıların oluşturdukları iş istekleri, kurumun BT çalışanlarına otomatik olarak görev şeklinde atanmaktadır. Düzenli iş akışları sayesinde kurumun BT çalışanları sadece kendi sorumluluk sahalarına giren iş isteklerini yanıtlamakta bu sayede zamandan tasarruf edilmekte ve gereksiz iş yükü ortadan kaldırılmaktadır. "SharePoint Designer" üzerinde iş akışlarının nasıl yapılandırıldığına dair bilgiler Şekil

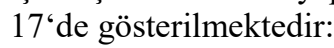

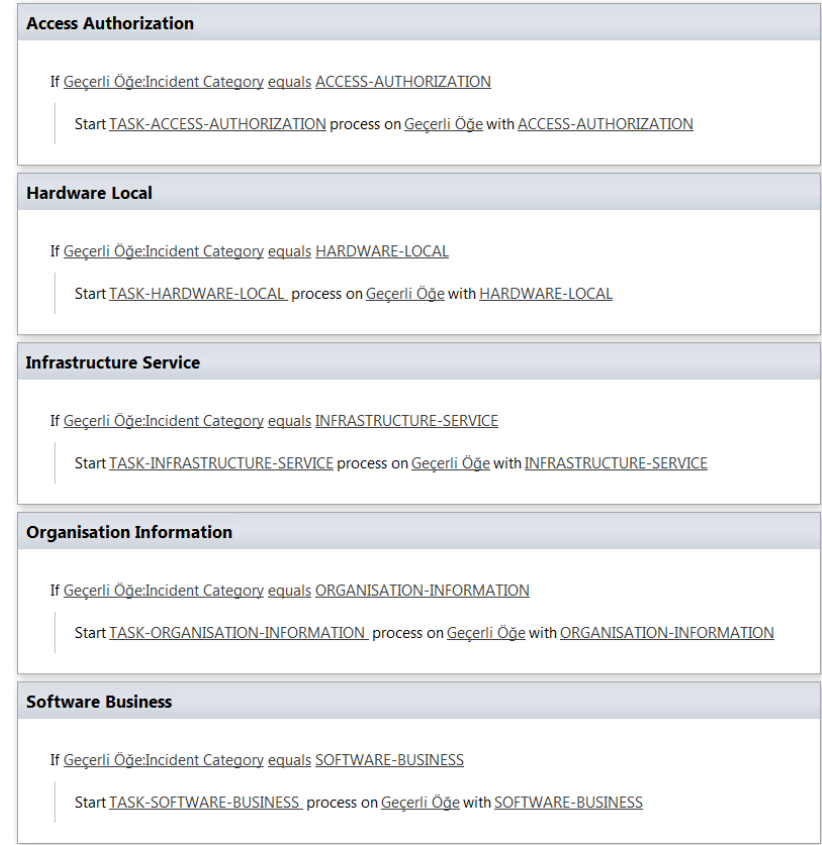

Şekil 17. SharePoint Designer Üzerinde İş Akışlarının Oluşturulması

(The Creation of Workflows on The SharePoint Designer)

\section{5. ÖRNEK UYGULAMA (SAMPLE APPLICATION)}

$\mathrm{Bu}$ bölümde geliştirilen uygulama ekran görüntüleriyle anlatılmaktadır. Kullanıcılar geliştirilen uygulamaya, etki alanı üyesi bir cihazdan, mobil ya da web ortamında herhangi bir internet tarayıcısına "http://bt" web adresini yazarak erişebilmektedir. Web sayfası açıldıktan sonra yeni bir öğe ekle (Add new item) düğmesine basıldığında Şekil 18'de gösterilen uygulama ana sayfası ile karşılașılmaktadır.

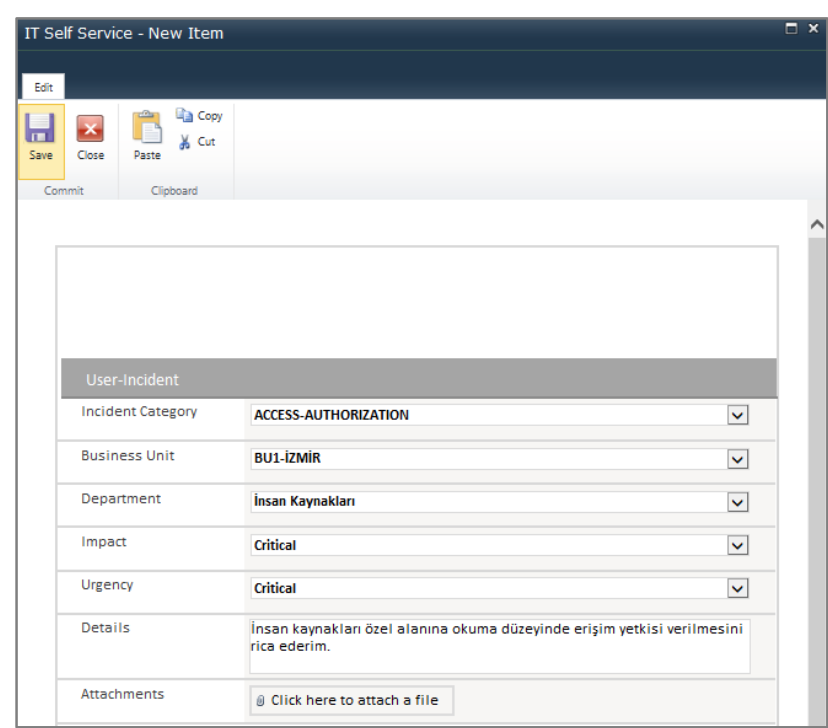

Şekil 18. Uygulama Arayüzü (Application Interface)

Kullanıcı iş isteğini uygulama arayüzüne girdikten sonra uygulamanın sol üst köşesinde yer alan kaydet (Save) düğmesine basarak iş isteğini tamamlamaktadır. $\mathrm{Bu}$ süreçten sonra iş akışı sistem tarafından otomatik olarak başlatılmakta ve iş isteği kullanıcının seçmiş olduğu olay kategorisine (Incident category) göre ilgili BT çalışanına görev olarak atanmaktadır. Atanan bu görevin öncelikle ilgili BT çalışanı tarafından iş akışları sayfasında kabul (Approve) edilmesi gerekmektedir. İş akışlarına ait örnek Şekil 19'da gösterilmektedir.

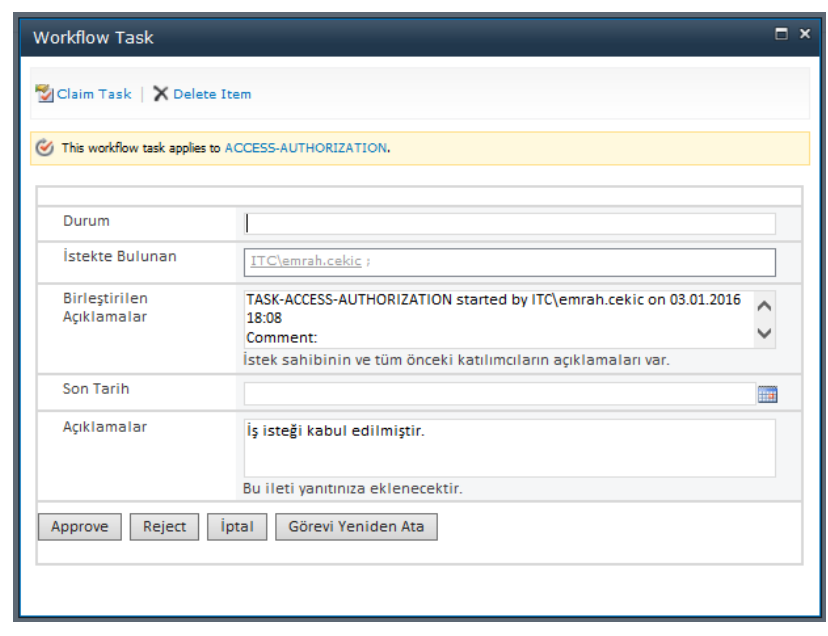

Şekil 19. Atanan İş İsteği (Assigned Work Request)

İlgili iş akışının BT bölümü çalışanı tarafından kabul edilmesinin ardından iş akışının sonuç (Outcome) bölümü kabul (Approve) olarak değişmektedir. $\mathrm{Bu}$ iş akışının durumunu takip etmek için gerekmektedir. Kabul edilen iş akışına ait kabul ekranı şekil 20’de gösterilmektedir. 


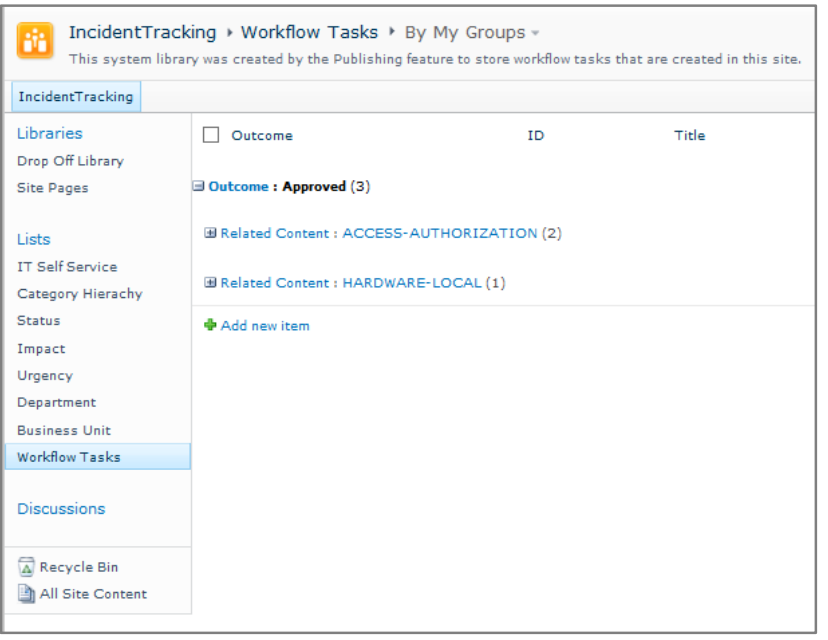

Şekil 20. İş İsteğini Kabul Etme (Acceptance of Work Request)

İş isteğinin kabulünü takiben BT bölümü çalışanı ilgili isteğe ait açıklamaları girerek iş akışını sonlandırmakta ve kullanıcının iş isteğini tamamladıktan sonra iş isteğini kapatmaktadır. Kapatılan iş isteğine ait örnek ekran görüntüsü Şekil 21 'de gösterilmektedir.

\begin{tabular}{|c|c|}
\hline \multicolumn{2}{|l|}{ User-Incident } \\
\hline Incident Category & ACCESS-AUTHORIZATION \\
\hline Business Unit & BU1-izmir \\
\hline Department & İnsan Kaynakları \\
\hline Impact & Critical \\
\hline Urgency & Critical \\
\hline Details & $\begin{array}{l}\text { İnsan kaynakları özel alanına okuma düzeyinde erişim yetkisi verilmesini } \\
\text { rica ederim. }\end{array}$ \\
\hline \multicolumn{2}{|l|}{ Attachments } \\
\hline \multicolumn{2}{|l|}{ IT-Incident Description } \\
\hline Incident ID & 50 \\
\hline Incident Created By & ITClemrah.cekic \\
\hline Category Hierachy & ACCESS-AUTHORIZATION-WORKMATE \\
\hline Status & Resolved \\
\hline Incident Modified By & ITClemrah.cekic \\
\hline \multicolumn{2}{|l|}{ IT-Total Elapsed Time } \\
\hline Incident Created & 03.01 .2016 \\
\hline Incident Closed & 03.01 .2016 \\
\hline \multicolumn{2}{|l|}{ Elapsed Time } \\
\hline IT Comments & Yetkilendirme yapıIImıştr. \\
\hline
\end{tabular}

Şekil 21. İş İsteğinin Kapatılması (Closing The Work Request)

Özel yetkilendirmeler sayesinde her kullanıcı sadece kendi oluşturduğu iş isteklerini görebilmekte ve olay izleme ana sayfasından (Incident Tracking) oluşturduğu iş isteklerinin durumunu görüntüleyebilmektedir. Kullanıcının BT bölümü tarafindan kapatılmış iş isteğine ait bilgilendirme ekranı Şekil 22'de gösterilmektedir.

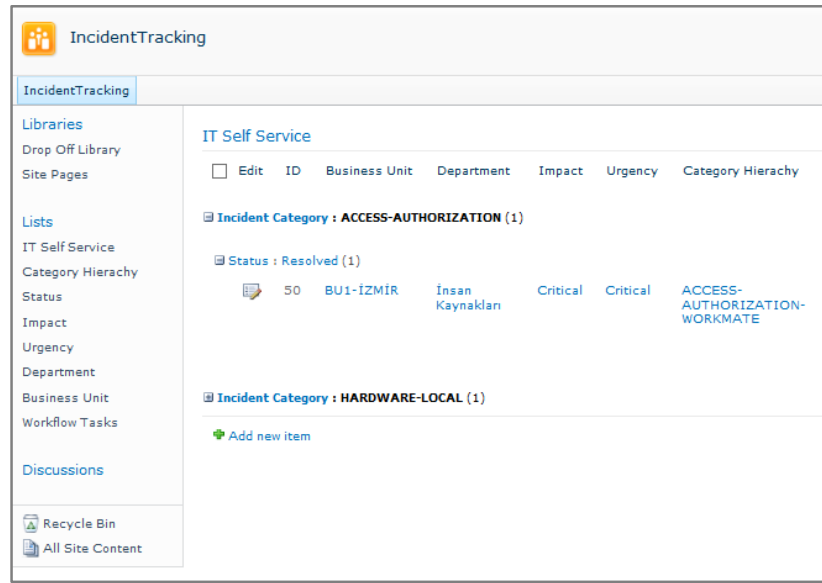

Şekil 22. Olay İzleme (Incident Tracking)

\section{VERILERINN ANALIZİ (ANALYSIS OF DATA)}

BT bölümlerine gelen iş isteklerinin geliştirilen uygulama üzerinden veritabanına kaydedilmesinin ardından, bu verilerin bilgiye dönüştürülebilmesi ve bilgilerin analiz edilerek yorumlanabilmesi konularına bu bölümde değinilmektedir. Bir Microsoft ürünü olan SharePoint, tüm Microsoft Office uygulamalarıyla bütünleşik olarak çalışmaktadır. Örnek uygulamada daha önce kaydedilmiş olan iş isteklerinin "Excel" ortamına aktarılması ve yorumlanması konularına değinilmiştir. Verilerin "Excel" ortamına aktarılması SharePoint yazılımının sağladığı kolaylıklardan sadece birisidir. Bu işlemi gerçekleştirmek için "Excel'e" aktar (Export to Excel) demek yeterlidir. Verilerin "Excel" ortamına aktarımı için gereken "Excel'e" aktar düğmesi Şekil 23'te gösterilmiştir.

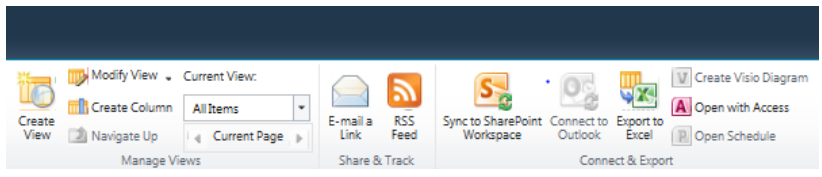

Şekil 23. Excel'e Aktarma (Export to Excel)

"Excel" ortamina aktarılan veriler SharePoint üzerinde tasarlanmış olan alan isimleriyle beraber gelmektedir. Bu sayede veriler üzerinden analiz yapmak kolaylaşmaktadır. $\mathrm{Bu}$ analizler BT bölümlerinin kurum çalışanlarına verdiği hizmetin, kalitesinin ölçümünde önemli bir rol oynamaktadır. Aynı zamanda BT bölümü çalışanlarının performans göstergelerinin ölçümü yapılarak bölüm içerisindeki çalışanların, bölüme sağladığı katma değerin ölçülmesi içinde kullanılabilir. "Excel” üzerine alınan verilere ait başlıkların bir bölümü Şekil 24'te gösterilmektedir. 


\begin{tabular}{|c|c|c|c|}
\hline 03.01.2016 17:51 & $03.01 .201619: 00$ & 1 EVREN KAMALI & ITClemrah.cekic \\
\hline $28.12 .201508: 22$ & $28.12 .201509: 40$ & 1 SINEM BAYLAN & ITClalpaslan.esel \\
\hline 03.01.2016 19:22 & $03.01 .201622: 00$ & 2 KEMAL SOYLU & ITClemrah.cekic \\
\hline $03.01 .201619: 23$ & $03.01 .201621: 25$ & 2 NIHAL SAYLAN & ITClalpaslan.esel \\
\hline $03.01 .201619: 24$ & $03.01 .201620: 00$ & 1 HASAN KUZGUN & ITClemrah.cekic \\
\hline
\end{tabular}

\section{Şekil 24. Verilerin Excel Üzerinde Gösterimi (View of Data on Excel)}

Örnek uygulamada verilerin "Excel” üzerine aktarımının ardından bu verilerden yola çıkılarak kurumun tesislerinden gelen iş isteklerinin durumlarına göre analiz edilmesi istenmektedir. "Excel" üzerinde olușturulan özet tablo (Pivot table) ile bu veriler analiz edilerek yorumlanmaktadır. Şekil 25 'te görüldüğü üzere en çok iş isteği "BU1-İZMİR" tesisinden yapılmış ve yapılan tüm iş istekleri sonuçlandırılmıştır. Bu analizden çıkarılan bir diğer sonuç ise şu şekilde ifade edilebilir. Kurumun BT bölümünün "BU1-KONYA" tesisine daha fazla zaman ayırması ve bekleyen iş isteklerini tamamlaması gerekmektedir. Bu ve benzeri birçok analizin "Excel" üzerinden yapılması mümkündür. Daha karmaşık iş analizleri için uygulama üzerindeki veri miktarının ve çeşitliliğinin artması beklenmektedir.

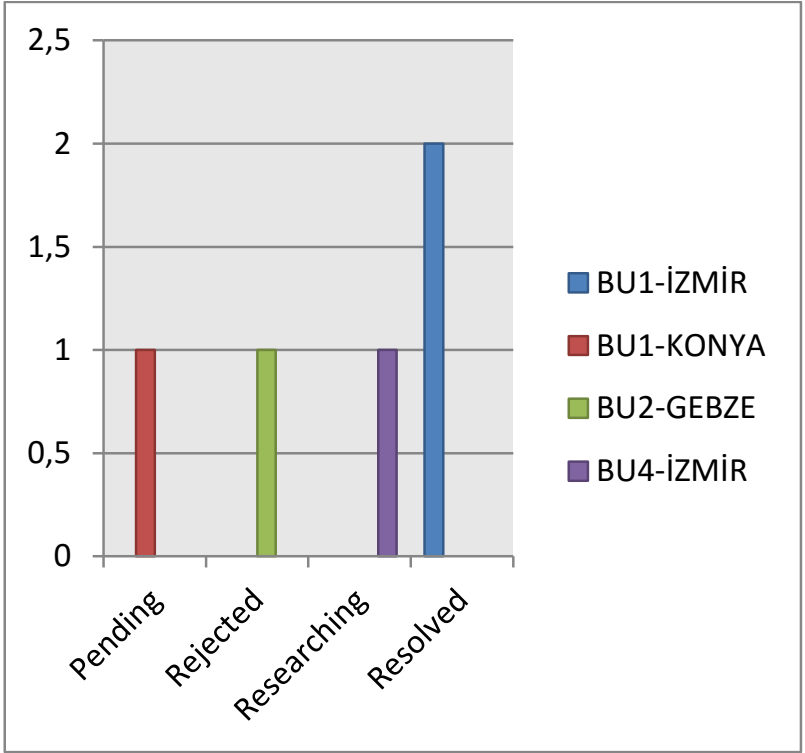

Şekil 25. Excel Üzerinde Veri Analizi (Data Analysis on Excel)

\section{SONUÇ VE DEĞERLENDİRME (RESULT AND EVALUATION)}

Makale kapsamında organizasyonlarda çalışan kullanıcıların BT bölümlerinden talep ettikleri iş isteklerini karşılamak ve organizasyonların BT bölümlerinin iş yükünü azaltmak amaciyla intranet tabanlı bir servis yönetimi uygulaması geliştirilmiştir. Uygulamanın geliştirilme safhalarında kurumun BT bölüm çalışanları ve son kullanıcıları ile interaktif bir ilişki kurulmuş olup böylelikle gelen geri bildirimlerle daha kapsamlı bir değerlendirme yapılmıştır.

Bu çalışma kurumların BT çalışanlarının en asgari yazılım bilgisiyle yüksek düzeyda yazılım geliştirme bilgisi gerektirmeksizin geliştirebileceği bir çalışma olmasının yanı sıra, kurum içi sistemlerle bütünleşik çalışması, uygulamanın etkinlik ve işlevselliğini artırmakta ve bu yönüyle kurumların BT bölümlerine katma değer yaratmaktadır. Üzerinde durulması gereken bir diğer önemli nokta ise bu uygulamanın özel bir kurumun dinamiklerinin gözetilerek geliştirilmiş olmasıdır. Bu yöntem, uygulamanın diğer kurumlarda kullanımına olanak sağlamaktadır. Ayrıca bu çalışma ile uygulamanın geliştirilmesi için harcanan zaman gözönüne alındığında hızlı uygulama gelişitirme ve iş süreçlerinin yönetimi açısından BT bölümlerine farklı uygulama istekleri için alternatif bir bakış açısı kazandıracağı düşünülmektedir.

Geliştirilen uygulamanın güçlü yanlarından biriside geliştirilme safhalarının anlaşılabilir ve tatbikinin kolay olmasıdır. Geliştirilen uygulamanın kurumların BT bölümlerine faydaları arasında ise, verilerin analizi konusu ön plana çıkmaktadır. Uygulama üzerinden toplanan verilerin ofis uygulamaları tarafindan yorumlanabilmesi sayesinde BT bölümlerinin hizmet kalitesi ölçülebilmekte ve BT çalışanlarının performans göstergeleri hesaplanabilmektedir. Aynı zamanda bölüm çalışanlarının dışarıdan destek aldığı noktalar iyi analiz edilerek dış kaynaklara yönelim engellenebilir veya iş gücünün yetersiz kaldığı sahalara personel alma kararı, bu analizler aracılığıyla doğru konumlandırılarak verilebilir.

Son olarak, literatür incelendiğinde gerçekleştirilen bu çalışmanın Microsoft firmasına ait olan SharePoint ürünü üzerinde, bu amaçla gerçekleştirilen öncü çalışmalar arasında olduğu gözlemlenmiştir. Bu yönüyle çalışmanın, kurumların BT bölümlerine deneyim ve tecrübenin aktarılması noktasında öncü çalışmalardan olacağını söylemek mümkündür.

\section{TEŞEKKÜR (ACKNOWLEDGMENT)}

Bu çalışma, İZMİR MAHLE MOTOR PARÇALARI A.Ş. yönetim bilişim sistemleri bölümü tarafından desteklenmiştir.

\section{KAYNAKLAR (REFERENCES)}

1. Esener, H., Hizmet Yönetimi Sistemi, Yüksek Lisans Tezi, Yıldız Teknik Üniversitesi, Fen Bilimleri Enstitüsü Bilgisayar Mühendisliği Anabilim Dalı, 2005.

2. Demirel, M.Y. ve İ. Karaağaç, Bilgisayar Destekli Üretim Süreçlerine Genel Bir Bakış. Engineer \& the Machinery Magazine, 2014. 1(652): p. 51-61.

3. Yılmaz, H., Bilgi Liderliğinin Işsletme Performansı Üzerine Etkilerinin Değerlendirilmesi. Optimum: Journal of Economics \& Management Sciences/Ekonomi ve Yönetim Bilimleri Dergisi, 2014. 1(1): p. 51 .

4. Demir, F., Kamu Kurumları Iç Ăg İletişim Portalı Tasarımı Türk Polis Teşkilatı Örneği. Polis Bilimleri Dergisi, 2015. 1(1): p. 75.

5. Weill, P. and S.L. Woerner, The Future of the CIO in a Digital Economy. MIS Quarterly Executive 2013: p. 65-75.

6. Gökşen, Y. ve H. Așan, Veri Büyüklüklerinin Veritabanı Yönetim Sistemlerinde Meydana Getirdiği Değişim: NOSQL. Bilișim Teknolojileri Dergisi, 2015. 8(3): p. 126. 
7. Hersh, M., Sustainable decision making: the role of decision support systems. Systems, Man, and Cybernetics, Part C: Applications and Reviews, IEEE Transactions on, 1999. 29(3): p. 395-408.

8. Druzdzel, M.J. and R.R. Flynn, Decision support systems. Encyclopedia of library and information science. A. Kent. Marcel Dekker, Inc. Last Login, 1999. 10(03): p. 2010.

9. Keen, P.G. and M.S.S. Morton, Decision support systems: an organizational perspective. Vol. 35. 1978: Addison-Wesley Reading, MA.

10. Oxley, A., Security Risks in Social Media Technologies: Safe practices in public service applications. 2013: Elsevier.

11. Deeptha, R. and R. Mukesh, Single Sign-on Mechanism for Secure Web Service Access through ISSO. Journal of Communications Software \& Systems, 2015. 11(1): p. 8-14.

12. Davis, F.D., R.P. Bagozzi, and P.R. Warshaw, User acceptance of computer technology: a comparison of two theoretical models. Management science, 1989. 35(8): p. 982-1003.

13. Kozak Akoğlan, M. ve V. Genç, Değisim Sürecinde Ortava Çlkan Direnci Önlemede Duyguların Yönetiminin Önemi: Hizmet İsletmeleri Açısından Bakış. Optimum Ekonomi ve Yönetim Bilimleri Dergisi, 2014. 1(2): p. 81-92.

14. İnternet: Logical Architecture, https://technet.microsoft.com/enus/library/cc263121(v=office.14).aspx, 01.06.2016

15. İnternet: VMware, http://www.vmware.com/tr/products/vspherehypervisor, 06.01.2016

16. İnternet: Active Directory, https://msdn.microsoft.com/enus/library/windows/desktop/aa746492(v=vs.85).aspx, 06.01.2016

17. İnternet: İs Akışları, https://support.office.com/trtr/article $/ \% \mathrm{C} 4 \% \mathrm{~B} 0 \% \mathrm{C} 5 \% 9 \mathrm{~F}-\% \mathrm{C} 4 \% \mathrm{~B} 1 \% \mathrm{C} 5 \% 9 \mathrm{Flar} \% \mathrm{C} 4 \% \mathrm{~B} 1$ nagiri $\%$ C5\%9F-ee1 efda5-82d8-4bb3-aa6b-544a2102fcff, 01.06 .2016 